\title{
Inozemstvo, Zagreb ili neki drugi grad u Hrvatskoj? Društveno porijeklo, racionalnost izbora i aspiracije srednjoškolaca prema mjestu studiranja
}

DOI: $10.5613 /$ rzs.50.2.6

UDK: $316.74: 37$

378(497.5):316.644-057.87

Izvorni znanstveni rad Primljeno: 6. 3. 2020.

\author{
Saša PUZIĆ (D) orcid.org/0000-0001-7231-7312 \\ Institut za društvena istraživanja u Zagrebu, Hrvatska \\ puzic@idi.hr \\ Josip ŠABIĆ (D) orcid.org/0000-0002-8981-2560 \\ Institut za društvena istraživanja u Zagrebu, Hrvatska \\ josip@idi.hr \\ Iva ODAK (D) orcid.org/0000-0002-4249-4964 \\ Institut za društvena istraživanja u Zagrebu, Hrvatska \\ iva@idi.hr
}

\section{SAŽETAK}

$U$ radu se ispituju aspiracije hrvatskih srednjoškolaca kad je riječ o mjestu studiranja (inozemstvo, Zagreb, drugi grad u Hrvatskoj). Teorijsko polazište rada čini teorija racionalnog izbora, koja se koristi pri objašnjenju obrazovnih odluka u periodu obrazovnih tranzicija. Provedena je višerazinska multinomijalna regresijska analiza na nacionalno reprezentativnom uzorku učenika četverogodišnjih srednjih škola $(N=10$ 829). Podatci su prikupljeni tijekom školske godine 2017./2018. Rezultati pokazuju da su aspiracije prema mjestu studiranja povezane s društvenim podrijetlom učenika: veće aspiracije prema studiranju u Zagrebu povezane su s visokoškolskim obrazovanjem barem jednog roditelja te s aktivnim radnim statusom majke i oca, dok su veće aspiracije za studiranjem u inozemstvu povezane $s$ visokoškolskim obrazovanjem obaju roditelja i višim mjesečnim prihodima kućanstva. Učeničke aspiracije prema studiranju u inozemstvu povezane su i s čimbenicima racionalnog izbora: većom brigom za izbjegavanjem silazne društvene mobilnosti, višom samoprocjenom vjerojatnosti uspješnog upisa i završetka studija, nižom procjenom vrijednosti obrazovanja u hrvatskom društvu te višom procjenom nepoštovanja meritokratskih principa u hrvatskom visokom obrazovanju. S druge strane, aspiracije prema studiranju u Zagrebu od navedenih su čimbenika povezane samo s višom procjenom društvene vrijednosti obrazovanja. Svi su učinci bili neovisni o školskom

Zahvaljujemo svim učenicima $\mathrm{i}$ odgojno-obrazovnim radnicima koji su sudjelovali u provedbi istraživanja NISpVU na kojem se temelji ovaj rad. 
uspjehu učenika. Dobiveni nalazi tumače se u kontekstu horizontalnih nejednakosti u visokom obrazovanju te se upućuje na moguće implikacije nalaza za obrazovnu politiku.

Ključne riječi: srednja škola, aspiracije prema mjestu studiranja, teorija racionalnog izbora, studiranje u inozemstvu, studiranje u Zagrebu, horizontalne nejednakosti

\section{UVOD}

Jedna od posljedica ekspanzije visokog obrazovanja u svijetu posljednjih desetljeća ogleda se u tome da su visokoškolske kvalifikacije postale dostupnije većem broju pojedinaca i stoga manje ekskluzivne (Netz i Finger, 2016). U literaturi (Lucas, 2001; Kraaykamp, Tolsma i Wolbers, 2013) se ističe da takav razvoj može potaknuti studente privilegiranog podrijetla da pokušaju ostvariti kvalitativne prednosti unutar visokog obrazovanja kako bi na taj način osigurali privilegirani položaj u društvu. Unatoč još nepotpunoj empirijskoj evidenciji (Gerber i Cheung, 2008; Lörtz, Netz i Quast, 2016), takva se pozicija teorijski objašnjava jačanjem horizontalnih nejednakosti u visokom obrazovanju (Arum, Gamoran i Shavit, 2007) koje, osim razlika u odabiru vrste (npr. sveučilišni ili stručni studij) i područja studija (npr. medicinske ili humanističke znanosti), mogu uključivati i razlike prema mjestu studiranja (npr. studiranje u inozemstvu ili na domaćem prestižnom sveučilištu).

Kad je riječ o mjestu studiranja, istraživanja upućuju na to da studiranje u inozemstvu pozitivno utječe na akademsko postignuće studenata, njihove jezične i interkulturne kompetencije, osobni razvoj, kao i na izglede za zapošljavanje nakon završetka studija (Dwyer, 2004; Lörtz i dr., 2016). No, usprkos pretpostavljenim prednostima studijske mobilnosti za pojedinca, u pojedinim se zemljama još uvijek razmjerno mali postotak studenata odlučuje za studiranje u inozemstvu ${ }^{1}$ (Hauschildt, Vögtle i Gwosc, 2018). U tu se skupinu zemalja ubraja i Hrvatska. Prema podatcima EUROSTUDENT istraživanja iz 2014. samo 2 \% studenata izjavilo je da su studirali u inozemstvu tijekom trajanja svoga studijskog programa², iako je interes za studijem u nekoj drugoj zemlji iskazalo čak 36 \% studenata (Šćukanec i dr., 2015). Dio objašnjenja tog nesrazmjera može se potražiti u odgovorima koji se odnose na prepreke međunarodnoj mobilnosti, među kojima se ponajprije izdvajaju dodatni troškovi povezani sa studijem u inozemstvu koje spominje gotovo 80 \% studenata (Hauschildt i dr., 2015). Ne iznenađuje stoga što studenti djeca viso-

\footnotetext{
1 Misli se na participaciju u službeno priznatom studijskom programu koji vodi formalnoj visokoškolskoj kvalifikaciji.

2 U spomenuto nisu uključeni boravci na ljetnim školama, stručnim praksama, tečajevima jezika i istraživački posjeti.
} 
koobrazovanih roditelja, koji u prosjeku imaju razmjerno veće financijske resurse od ostalih (Sirin, 2005), značajno češće namjeravaju provesti određeno razdoblje studija u nekoj drugoj zemlji od studenata čiji roditelji nisu studirali (Šćukanec i dr., 2015). Taj nalaz upućuje na činjenicu da je studiranje u inozemstvu društveno selektivan proces, što pokazuju i postojeća međunarodna istraživanja (npr. Di Pietro i Page, 2008; Lörtz i dr., 2016; Hauschildt i dr., 2018). Štoviše, različiti autori (Lörtz i dr., 2016; Netz i Finger, 2016) taj nalaz interpretiraju tako da studiranje $\mathrm{u}$ inozemstvu promatraju kao novi mehanizam društvene reprodukcije u visokom obrazovanju odnosno kao novi oblik horizontalnih nejednakosti. To se stajalište aktualizira u kontekstu Europskog prostora visokog obrazovanja (engl. European Higher Education Area) u kojem se potiče suradnja visokoškolskih institucija kroz razmjenu studenata i nastavnika te razvoj zajedničkih studijskih programa (de Wit i Hunter, 2018). Jer, premda se proces stvaranja Europskog prostora visokog obrazovanja ${ }^{3}$ potiče kroz mnogobrojne europske inicijative, njegovi se učinci rijetko propituju (Powell i Finger, 2013) pa tako ni činjenica "da ideal prostorne mobilnosti postiže samo manjina studenata u visokom obrazovanju” (Powell i Finger, 2013).

Uz selekcijske procese povezane sa studijem u inozemstvu, horizontalne nejednakosti mogu uključivati i selekcijske procese prema mjestu studija unutar nacionalnih sustava visokog obrazovanja (Davies i Guppy, 1997). Kad je riječ o Hrvatskoj, za potonje mogu biti indikativni podatci o stupnju obrazovanja roditelja studenata na četirima najvećim hrvatskim sveučilištima (Zagreb, Rijeka, Split, Osijek) koji pokazuju da je udio studenata čiji roditelji imaju visoko obrazovanje tradicionalno najveći na Sveučilištu u Zagrebu, a najmanji na Sveučilištu u Osijeku (Previšić, 1978; Šćukanec i dr., 2015). Selekcijski procesi u visokom obrazovanju mogu se također dovesti u vezu s razlikama u poželjnosti studija u različitim gradovima u Hrvatskoj, gdje otprilike polovina svih učenika srednjih škola i približno 66 $\%$ onih najuspješnijih želi kao svoj prvi izbor upisati studijski program u Zagrebu, a samo manji dio u nekom od drugih (Split, Osijek, Rijeka) sveučilišnih centara (Jokić i Ristić Dedić, 2014). Navedeni podatci o aspiracijama prema mjestu studiranja upućuju na procese diferenciranja unutar hrvatskog sustava visokog obrazovanja, iako pritom ostaje nejasno koliko su ti procesi uvjetovani društvenim podrijetlom učenika, odnosno studenata.

Budući da društvena selektivnost aspiracija za studiranjem u Hrvatskoj ili inozemstvu nije bila u fokusu dosadašnjih istraživanja u hrvatskom kontekstu, u ovom se radu ispituje važnost različitih čimbenika povezanih s društvenim podrijetlom hrvatskih srednjoškolaca za aspiracije prema mjestu studiranja. Pritom se polazi od teorijske perspektive koja se često koristi pri analizi obrazovnih tranzicija u više razine obrazovanja - teorije racionalnog izbora (Boudon, 1974; Goldthorpe, 1996).

Taj zajednički model mobilnosti u međuvremenu obuhvaća 48 zemalja (Study.EU, 2020). 


\section{TEORIJA RACIONALNOG IZBORA U KONTEKSTU OBRAZOVNIH NEJEDNAKOSTI}

Teorija racionalnog izbora polazi od razlikovanja primarnih i sekundarnih učinaka društvenog podrijetla (Boudon, 1974), pri čemu se primarnim učinkom smatra utjecaj društvenog podrijetla na obrazovni uspjeh učenika, a sekundarnim učinkom utjecaj društvenog podrijetla na obrazovne odluke učenika (neovisno o uspjehu). Obrazovne odluke učenika posljedica su razmatranja troškova, koristi i izgleda za uspjeh s obzirom na klasno podrijetlo obitelji (Breen i Goldthorpe, 1997). U tom se sklopu osobito ističe važnost motiva za održanjem obiteljskog statusa budući da svoje obrazovne odluke i profesionalne aspiracije učenici formiraju u odnosu na društveni položaj svojih roditelja (obitelji): "[Obitelji] žele izbjeći, za svoju djecu, svaki položaj u životu koji je gori od onog od kojeg počinju” (Breen i Goldthorpe, 1997: 238). Pritom, i roditelji i djeca, iz svih slojeva, nastoje izbjeći silaznu mobilnost više nego što žele ostvariti uzlaznu mobilnost. $S$ obzirom na to da djeca iz privilegiranih obitelji trebaju za održanje obiteljskog statusa postići viši obrazovni uspjeh od djece iz nižih klasa, mehanizam izbjegavanja silazne društvene mobilnosti, odnosno "izbjegavanja relativnog rizika” kako ga nazivaju Breen i Goldthorpe (1997), u konačnici pridonosi ograničenoj uzlaznoj mobilnosti i održanju postojećih nejednakosti među klasama.

Sa stajališta teorije racionalnog izbora, aspiracije prema mjestu studiranja ovisit će o različitim čimbenicima koji utječu na to da se ono percipira kao korisno za održanje obiteljskog statusa. $U$ tom se sklopu aspiracije prema mjestu studiranja mogu vezati uz brigu učenika za izbjegavanje silazne društvene mobilnosti, uz subjektivno percipirane izglede za uspješan završetak studija, procjene troškova studija ili vrijednost i korist koju djeca i obitelji pridaju obrazovnim ishodima (usp. Breen i Goldthorpe, 1997; Van de Werfhorst i Hofstede, 2007; Becker i Hecken, 2009; Lörtz i dr., 2016). Aspiracije prema mjestu studiranja mogu se vezati i uz percepciju širih društvenih čimbenika koji mogu oblikovati koristi od visokog obrazovanja - pritom se misli na kontekstualne čimbenike, poput stavova prema visokom obrazovanju ili njegovim pojedinim elementima (npr. prema kvaliteti obrazovnih ishoda ili poštovanju meritokratskih principa), koji mogu biti relevantni u razmatranju obrazovnih troškova i koristi (usp. Stocké i dr., 2011). Pod pretpostavkom da širenje sustava visokog obrazovanja rezultira slabljenjem veze između visokoškolskih kvalifikacija i društvene stratifikacije (Van de Werfhorst i Luijkx, 2010), učenici iz privilegiranih obitelji mogu pokušati svoj privilegirani obiteljski status osigurati s pomoću prestižnijih oblika visokog obrazovanja, primjerice u inozemstvu ili unutar prestižnijega sveučilišnog centra. Kad je riječ o studiranju u inozemstvu, u različitim se istraživanjima upućuje na njegovu društvenu selektivnost, pri čemu se ističu 
razlike u procesu donošenja odluka između društvenih grupa. Lörtz i dr. (2016) tako navode da studenti nižega društvenog statusa rjeđe studiraju u inozemstvu zbog većih troškova studija, ali i zbog nižeg očekivanja dobrobiti koju bi mogli imati odlaskom na studij u inozemstvo. Na tom tragu Salisbury i dr. (2009) ukazuju na tendenciju precjenjivanja troškova, posebno potrebnog vremena i propuštene zarade, i podcjenjivanja obrazovne dobrobiti studiranja u inozemstvu od strane studenata nižega socioekonomskog statusa. Netz i Finger (2016) ističu kako se stratifikacija unutar sustava visokog obrazovanja očituje u količini vremena koju studenti provedu u inozemstvu - studenti privilegiranoga društvenog podrijetla provode prosječno više vremena u inozemstvu od studenata nižega društvenog statusa, što im omogućuje bolje usvajanje stranog jezika i interkulturnih kompetencija.

U ovom se radu analiziraju aspiracije hrvatskih učenika prema mjestu studiranja na temeljima teorije racionalnog izbora, $s$ fokusom na izbjegavanju silazne društvene mobilnosti (Breen i Goldthorpe, 1997). Shvaćanje procesa društvene diferencijacije prema mjestu studiranja temelji se na analizi procesa povezanih uz odlučivanje učenika prilikom prijelaza iz srednjeg u visoko obrazovanje, dakle ne analizira se sama obrazovna odluka, nego učeničke aspiracije kad je posrijedi najpoželjnije mjesto studiranja. Pritom se aspiracije prema mjestu studiranja ne promatraju samo vezano uz društveno podrijetlo učenika, nego i uz učeničku procjenu vjerojatnosti upisa i završetka studija, procjenu društvene vrijednosti obrazovanja te učeničku percepciju nepoštovanja meritokratskih principa u visokom obrazovanju u Hrvatskoj.

\section{CILJ ISTRAŽIVANJA}

Osnovni je cilj rada ispitati važnost društvenog podrijetla i različitih čimbenika vezanih uz teoriju racionalnog izbora za aspiracije za studiranjem u inozemstvu i u Zagrebu u odnosu na studiranje u nekom drugom gradu u Hrvatskoj. Na taj se način želi utvrditi pružaju li aspiracije za studiranjem u inozemstvu i u Zagrebu osnovu za razvoj horizontalnih nejednakosti u visokom obrazovanju u hrvatskom kontekstu. Kod formulacije spomenutoga cilja krenulo se od pretpostavke da su studij u inozemstvu i studij u Zagrebu poželjniji izbor za učenike privilegiranoga društvenog podrijetla u odnosu na studij u nekom drugom gradu u Hrvatskoj (Šćukanec i dr., 2015; Netz i Finger, 2016).

U svrhu ostvarenja spomenutoga cilja ispituje se postoje li neovisni doprinosi društvenog podrijetla (obrazovanje roditelja, radni status roditelja i prihodi kućanstva) i različitih čimbenika vezanih uz teoriju racionalnog izbora (izbjegavanje silazne društvene mobilnosti, samoprocjena vjerojatnosti uspješnog upisa i završetka studija, procjena društvene vrijednosti obrazovanja i procjena nepoštovanja me- 
ritokratskih principa u visokom obrazovanju u Hrvatskoj) u objašnjenju učeničkih aspiracija prema različitim mjestima studiranja (Zagreb, neki drugi grad u Hrvatskoj i inozemstvo).

\section{METODOLOGIJA}

\subsection{Uzorak}

Rad je nastao u sklopu većega istraživačkog projekta "Analiza stanja i potreba u srednjoškolskom odgoju i obrazovanju vezanih uz informiranje o visokoškolskim izborima i postupcima upisa na studijske programe preko Nacionalnoga informacijskog sustava prijava na visoka učilišta (NISpVU)" što su ga proveli znanstvenici Instituta za društvena istraživanja u Zagrebu u suradnji s Agencijom za znanost i visoko obrazovanje. U projektu su se istraživale želje srednjoškolaca za nastavkom obrazovanja na visokoškolskoj razini u kontekstu njihovih životnih planova, interesa za pojedina područja učenja i rada, čimbenika odabira studijskih programa, informiranosti o prijelazu iz srednjega u visoko obrazovanje, percepcije Hrvatske kao obrazovnog konteksta te uvjerenosti u ostvarivanje pozitivnih ishoda povezanih s prijelazom iz srednjega u visoko obrazovanje (Ristić Dedić i Jokić, 2019). Baza podataka korištena u ovom radu prikupljena je tijekom školske godine 2017./2018. te sadržava podatke učenika prvih, trećih i završnih razreda četverogodišnjih i petogodišnjih srednjoškolskih programa iz 59 škola, što predstavlja otprilike $16 \%$ od ukupnog broja škola u Hrvatskoj u kojima se takvi programi provode. lako je cjelokupna baza sadržavala podatke 13301 učenika, u ovom su radu korišteni podatci 10797 učenika (81,2 \%) koji su na česticu “U budućnosti želim studirati” odgovorili potvrdno, tj. onih učenika koji su izrazili želju za studiranjem. Škole su odabrane po slučaju unutar stratuma definiranih geografskom lokacijom (u tu svrhu, Hrvatska je podijeljena na šest regija: 1. Dalmacija, 2. Istra i Hrvatsko primorje, 3. Sjeverozapadna Hrvatska, 4. Slavonija, 5. Središnja Hrvatska i 6. Zagreb i okolica) i tipom srednjoškolskog programa koji se izvode u školi (isključivo gimnazijski programi, isključivo strukovni programi, te mješovite škole u kojima se izvode i strukovni i gimnazijski programi). U svakoj školi, barem jedan razredni odjel odabran je po slučaju i pozvan na sudjelovanje u istraživanju. U većini škola (88 \%), u istraživanju su sudjelovala dva ili više razrednih odjela po svakoj godini školovanja. Podatci su prikupljeni upitnikom koji su učenici ispunili u svojim školama za vrijeme nastave u trajanju od jednoga školskog sata. $U$ tu su svrhu prikupljeni informirani pristanci roditelja učenika. 


\subsection{Mjere}

\subsubsection{Kriterijska varijabla}

Najpoželjnije mjesto za studiranje. Kao kriterijska varijabla u ovom radu korištena je čestica upitnika “Koje je za tebe najpoželjnije mjesto za studiranje?”. Učenici su mogli odabrati između sljedećih odgovora: "Zagreb", "Regionalni sveučilišni centar", "Neki drugi grad u Hrvatskoj”, "Neka EU zemlja” i "Neka druga zemlja izvan EU-a". S obzirom na relativno mali udio učenika koji su odabirali kategorije "Neki drugi grad u Hrvatskoj" (4,5 \%) i "Neka druga zemlja izvan EU-a" (4,9 \%), te radi lakše interpretacije i zornosti prikaza rezultata, u ovom smo radu odgovore "Regionalni sveučilišni centar" i "Neki drugi grad u Hrvatskoj" spojili u kategoriju "Neki drugi grad u Hrvatskoj", a odgovore "Neka EU zemlja" i "Neka druga zemlja izvan EU-a" u kategoriju "Inozemstvo". Na taj smo način dobili kriterijsku varijablu s trima kategorijama odgovora: "Zagreb", “Neki drugi grad u Hrvatskoj” i “Inozemstvo".

\subsubsection{Glavne regresorske varijable}

Društveno podrijetlo. Mnogobrojna istraživanja ukazuju na veze društvenog podrijetla i učeničkih obrazovnih aspiracija (npr. Sewell i Shah, 1968; Walpole, 2003). Kao uobičajene mjere društvenog podrijetla učenika, tj. njihovih obitelji, koriste se obrazovanje roditelja, radni status roditelja i procijenjeni prihodi kućanstva.

- Obrazovanje roditelja. Učenici su trebali označiti najviši završeni stupanj obrazovanja majke i oca (dvije čestice s ponuđenim odgovorima: "Završena osnovna škola”, "Završena srednja škola” i “Završena viša škola ili fakultet”). Njihovi odgovori na te dvije čestice rekodirani su prema najvišem stupnju obrazovanja roditelja u jednu varijablu s kategorijama "Oba roditelja imaju završenu osnovnu školu", "Barem jedan roditelj ima završenu srednju školu”, "Oba roditelja imaju završenu srednju školu”, "Barem jedan roditelj ima završenu višu školu ili fakultet” i "Oba roditelja imaju završenu višu školu ili fakultet".

- Radni status roditelja. Po jedna čestica upitnika odnosila se na radni status majke i oca, pri čemu su učenici mogli birati između sljedećih ponuđenih odgovora: "Zaposlen/a", "Nezaposlen/a", "Umirovljenik/ica" i "Ne znam/ne odnosi se na mene". $U$ analizi, te su dvije čestice korištene kao zasebni regresori.

- Prihodi kućanstva. Od učenika je zatraženo da procijene ukupne mjesečne prihode svog kućanstva. Mogući odgovori bili su: "Do 5000 kn", "5 000 - 10 000 kn”, "10 000 - 15000 kn”, "Više od 15000 kn" i “Ne mogu procijeniti”. 
Izbjegavanje silazne društvene mobilnosti. Korišten je hrvatski prijevod skale Van de Werfhorsta i Hofstedea (2007: 399) koja se sastojala od sljedećih šest čestica: "Važno mi je imati bolji posao nego moji roditelji", "Želim postići viši stupanj obrazovanja od mojih roditelja", "Važno mi je kasnije u životu zarađivati barem koliko i moji roditelji", "Mojim se roditeljima ne bi svidjelo kad bih imao/la lošiji posao od njihovog”, "Želim imati jednako visok položaj na društvenoj ljestvici kao i moji roditelji" i "Brine me da ću kasnije u životu imati niži status u društvu od mojih roditelja”. Učenici su navedene tvrdnje procjenjivali na skali od pet stupnjeva (od "Uopće ne" do "U potpunosti da"). Vrijednost Cronbachovog a koeficijenta iznosila je 0,69 što ukazuje na osrednju unutarnju konzistenciju skale. Metodom glavnih osi (engl. principal axis factoring) utvrđen je jedan dominantan faktor kojim je objašnjeno $40,6 \%$ varijance te dodatni faktor kojim je objašnjeno $17,5 \%$ varijance. Kako dodatni faktor nije imao teorijsko utemeljenje, u radu smo rezultat na skali formirali kao prosjek učeničkih procjena na svim česticama.

Samoprocjena vjerojatnosti uspješnog upisa i završetka studija. Osim motiva za izbjegavanjem silazne društvene mobilnosti, samoprocjena vjerojatnosti upisa i završetka studija može predstavljati važan aspekt odabira vezanih uz studij (Lörtz i dr., 2016). Kao mjera tog konstrukta poslužio je prosjek učeničkih procjena na trima česticama upitnika ("Koliko si uvjeren/a da ćeš uspješno...: "Položiti ispite državne mature", "Upisati željeni studij” i "Završiti željeni studij”?). Procjene su bile na skali od pet stupnjeva od "Uopće nisam uvjeren/a" do "Izrazito sam uvjeren/a". Skala je imala razmjerno visoku unutarnju konzistenciju (Cronbachov $\alpha=0,80$ ), a metodom glavnih osi utvrđen je jedan dominantan faktor kojim je objašnjeno 71,4 $\%$ varijance.

Procjena društvene vrijednosti obrazovanja. Ako učenici smatraju da obrazovanje u hrvatskom društvu nije prepoznato kao vrijednost, može se očekivati da će biti skloniji izražavanju aspiracije za studiranjem u nekoj drugoj zemlji. Od učenika se u upitniku tražilo da na skali od četiri stupnja (od "Uopće se ne slažem" do "U potpunosti se slažem") procijene svoje slaganje s tvrdnjom: "U Hrvatskoj se obrazovanje cijeni."

Procjena nepoštovanja meritokratskih principa u visokom obrazovanju u Hrvatskoj. S obzirom na to da bi obrazovni uspjeh trebao biti vezan uz meritokratske principe vrednovanja, može se pretpostaviti da procjena nepoštovanja meritokratskih principa u visokom obrazovanju u Hrvatskoj može utjecati na učeničke aspiracije prema mjestu studiranja. Od učenika se tražilo da na skali od četiri stupnja (od "Uopće se ne slažem" do "U potpunosti se slažem") procijene svoje slaganje sa sljedećom tvrdnjom: "Za upis na fakultet u Hrvatskoj važnije su druge stvari (snalažljivost, osobne veze, roditelji...) od sposobnosti učenja." 


\subsubsection{Kontrolne regresorske varijable}

S obzirom na nedostatak istraživanja o aspiracijama kad je posrijedi mjesto studiranja među hrvatskim učenicima, u ovom smo radu odlučili kontrolirati učinke varijabli za koje se u ranijim istraživanjima pokazalo da su povezane s aspiracijama za studijem općenito.

Vrsta srednjoškolskog obrazovanja. S obzirom na razlike između učenika gimnazijskih i strukovnih programa u obrazovnim aspiracijama koje su utvrđene u drugim istraživanjima (npr. Šabić, 2019), kontrolira se vrsta srednjoškolskog obrazovanja koje učenici pohađaju (gimnazijsko ili strukovno).

Rod. Budući da djevojke od osnovnoškolske dobi iskazuju višu razinu visokoškolskih aspiracija od mladića (npr. Šabić i Jokić, 2019), a također i češće upisuju tercijarno obrazovanje (Državni zavod za statistiku, 2018), kontrolira se učinak roda na aspiracije prema mjestu studiranja.

Godina školovanja. U prethodnim istraživanjima utvrđeno je kako postoje određene dobne razlike u obrazovnim aspiracijama, primjerice da učenici viših razreda srednje škole u većem udjelu izražavaju želju za studiranjem od učenika nižih razreda (npr. Jokić, 2019). Stoga je u analizu uvrštena i varijabla razreda, tj. godine školovanja. U našem istraživanju, sudionici su bili učenici prvoga, trećeg i završnog razreda (tj. četvrtog razreda u većini škola ili petog razreda nekih srednjih medicinskih programa).

Školski uspjeh. Učenici višega školskog uspjeha u prosjeku imaju i više aspiracije za daljnje školovanje (npr. Puzić, Odak, Šabić, 2019; Šabić i Jokić, 2019). Školski uspjeh je operacionaliziran kao zbroj zaključnih ocjena iz Hrvatskog jezika, Matematike i Prvoga stranog jezika (za većinu učenika to su Engleski jezik ili Njemački jezik) na kraju prethodne školske godine. Navedeni su predmeti relevantni za analizu jer čine obvezni dio ispita državne mature, o kojoj uvelike ovisi i upis studija.

Mjesto školovanja. Kao kontrolna varijabla na razini škole korištena je informacija o mjestu u kojem se nalazi srednja škola koju je učenik pohađao. Pritom su korištene kategorije "Zagreb" i "Neko drugo mjesto". Mjesto školovanja bilo je potrebno kontrolirati jer se očekuje da će učenici iz Zagreba u prosjeku biti skloniji studiranju Zagrebu od učenika iz drugih mjesta u Hrvatskoj i obratno. 


\subsection{Statističke analize}

S obzirom na činjenicu da su učenici smješteni unutar škola kao jedinica uzorkovanja, tj. da je riječ o "ugniježđenom" uzorku (engl. nested sample) korištena je višerazinska multinomijalna regresijska analiza (npr. Heck, Thomas i Tabata, 2012; Hox, Moerbeek i van de Schoot, 2018). Pritom je kao kriterijska varijabla korištena kategorijalna varijabla odgovora na pitanje "Koje je za tebe najpoželjnije mjesto za studiranje?". Kategorija "Neki drugi grad u Hrvatskoj" u analizi je korištena kao referentna, a parametri su procjenjivani za kategorije "Zagreb" i "Inozemstvo". Kako bi se kontrolirala eventualna odstupanja od pretpostavki statističkog modela korištene su robusne procjene parametara (npr. Heck i dr., 2012). Intraklasni koeficijent korelacije (engl. intraclass correlation coefficient) za kategoriju "Zagreb" iznosi 0,37 , jednako kao i za kategoriju "Inozemstvo", iz čega proizlazi kako se više od trećine varijabiliteta u kriterijskoj varijabli aspiracija prema mjestu studiranja može objasniti time što učenici pohađaju različite škole. Taj nalaz opravdava odluku o provedbi višerazinske umjesto jednorazinske analize. Većina je učenika $(88,9 \%)$ dala odgovore na sve čestice upitnika, što je rezultiralo gotovo u potpunosti ispunjenom bazom podataka ( $98,8 \%$ ispunjenih ćelija). Postotci neispunjenosti ćelija po pojedinim varijablama bili su relativno niski $(\leq 4,0 \%)$. Prema literaturi (npr. Schafer, 1999; Dong i Peng, 2013), postotci neispunjenosti varijabli do $5 \%$ nemaju utjecaja na zaključke koji proizlaze iz analiza. Stoga smo odlučili provesti analize na podatcima učenika koji su odgovorili na sve korištene čestice upitnika. Sve vrijednosti faktora inflacije varijance (engl. variance inflation factors; VIF) bile su manje od dva, iz čega proizlazi kako nisu postojali problemi s multikolinearnošću.

\section{REZULTATI}

\subsection{Karakteristike učenika s obzirom na demografiju, društveno podrijetlo i čimbenike racionalnog izbora}

U Tablici 1. prikazani su deskriptivni statistički podatci o varijablama korištenima u radu. Većini učenika iz uzorka oba roditelja imaju srednju školu kao najviši završeni stupanj obrazovanja. Nadalje, većini su učenika roditelji zaposleni, a prihodi njihovih kućanstava uglavnom su u rasponu od 5000 do 15000 kuna. Na skali izbjegavanja silazne društvene mobilnosti prosječan rezultat nalazi se u području srednjih vrijednosti. Učenici u prosjeku daju visoke samoprocjene vjerojatnosti uspješnog upisa i završetka studija. U prosjeku, učenici izvještavaju o osrednjim razinama društvene vrijednosti obrazovanja. Prosječna procjena nepoštovanja 
meritokratskih principa u visokom obrazovanju u Hrvatskoj je visoka, tj. učenici u prosjeku smatraju kako su za upis na fakultet u Hrvatskoj važnije druge stvari od sposobnosti učenja. Više od polovine učenika smatra kako je najpoželjnije mjesto za studiranje Zagreb.

Tablica 1. Deskriptivna statistika korištenih varijabli

\begin{tabular}{|c|c|c|c|c|}
\hline Varijabla & $\mathrm{M}, \%$ & SD & Raspon & Cronbach \\
\hline \multicolumn{5}{|l|}{ Regresorske varijable } \\
\hline \multicolumn{5}{|l|}{ Razina učenika } \\
\hline \multicolumn{5}{|l|}{ Kontrolne varijable } \\
\hline \multicolumn{5}{|l|}{ Vrsta srednjoškolskog obrazovanja } \\
\hline Gimnazijsko & 55,7 & & & \\
\hline Strukovno & 44,3 & & & \\
\hline \multicolumn{5}{|l|}{ Rod } \\
\hline Muški & 42,5 & & & \\
\hline Ženski & 57,5 & & & \\
\hline \multicolumn{5}{|l|}{ Razred } \\
\hline 1. razred & 31,7 & & & \\
\hline 3. razred & 33,3 & & & \\
\hline Završni razred & 35,0 & & & \\
\hline Školski uspjeh & 11,6 & 2,43 & $6-15$ & 0,74 \\
\hline \multicolumn{5}{|l|}{ Društveno podrijetlo } \\
\hline \multicolumn{5}{|l|}{ Obrazovanje roditelja } \\
\hline Oba roditelja osnovna škola & 1,2 & & & \\
\hline Jedan roditelj srednja škola & 4,9 & & & \\
\hline Oba roditelja srednja škola & 42,0 & & & \\
\hline Jedan roditelj viša škola ili fakultet & 28,1 & & & \\
\hline Oba roditelja viša škola ili fakultet & 23,9 & & & \\
\hline \multicolumn{5}{|l|}{ Radni status majke } \\
\hline Nezaposlena & 17,1 & & & \\
\hline Umirovljenica & 2,0 & & & \\
\hline Ne znam / Ne odnosi se na mene & 1,5 & & & \\
\hline Zaposlena & 79,4 & & & \\
\hline \multicolumn{5}{|l|}{ Radni status oca } \\
\hline Nezaposlen & 4,6 & & & \\
\hline Umirovljenik & 10,4 & & & \\
\hline Ne znam / Ne odnosi se na mene & 2,8 & & & \\
\hline Zaposlen & 82,2 & & & \\
\hline
\end{tabular}




\begin{tabular}{|c|c|c|c|c|}
\hline Varijabla & $\mathrm{M}, \%$ & SD & Raspon & Cronbachov a \\
\hline \multicolumn{5}{|l|}{ Prihodi kućanstva } \\
\hline Do 5000 kn & 7,7 & & & \\
\hline $5000-10000 \mathrm{kn}$ & 28,1 & & & \\
\hline $10000-15000 \mathrm{kn}$ & 26,0 & & & \\
\hline Ne mogu procijeniti & 16,1 & & & \\
\hline Više od 15000 kn & 22,1 & & & \\
\hline \multicolumn{5}{|l|}{ Racionalni izbor } \\
\hline $\begin{array}{l}\text { Izbjegavanje silazne društvene } \\
\text { mobilnosti }\end{array}$ & 3,3 & 0,74 & $1-5$ & 0,69 \\
\hline $\begin{array}{l}\text { Samoprocjena vjerojatnosti uspješnog } \\
\text { upisa i završetka studija }\end{array}$ & 3,9 & 0,67 & $1-5$ & 0,80 \\
\hline $\begin{array}{l}\text { Procjena društvene vrijednosti } \\
\text { obrazovanja }\end{array}$ & 2,5 & 0,84 & $1-4$ & \\
\hline $\begin{array}{l}\text { Procjena nepoštovanja meritokratskih } \\
\text { principa u visokom obrazovanju u } \\
\text { Hrvatskoj }\end{array}$ & 2,8 & 0,92 & $1-4$ & \\
\hline \multicolumn{5}{|l|}{ Razina škole } \\
\hline \multicolumn{5}{|l|}{ Kontrolna varijabla } \\
\hline \multicolumn{5}{|l|}{ Mjesto školovanja } \\
\hline Zagreb & 25,8 & & & \\
\hline Druga mjesta & 74,2 & & & \\
\hline \multicolumn{5}{|l|}{ Kriterijska varijabla } \\
\hline \multicolumn{5}{|l|}{ Najpoželjnije mjesto za studiranje } \\
\hline Zagreb & 51,6 & & & \\
\hline Neki drugi grad u RH & 28,0 & & & \\
\hline Inozemstvo & 20,4 & & & \\
\hline
\end{tabular}




\subsection{Veze društvenog podrijetla i čimbenika racionalnog izbora s aspiracijama učenika prema mjestu studiranja}

U Tablici 2. prikazani su rezultati višerazinske multinomijalne regresijske analize. Ta analiza rezultira odvojenim setovima procjena parametara za svaku pojedinu kategoriju kriterijske varijable s iznimkom referentne kategorije. U ovom radu kao referentnu kategoriju odabrali smo "Neki drugi grad u Hrvatskoj" pa su parametri procijenjeni za kategorije "Zagreb" i "Inozemstvo".

Nalazi ove analize vezani za regresorske varijable koje se odnose na društveno podrijetlo pokazuju da učenici kojima jedan ( $B=-0,36$; $p<0,05$ ) ili oba roditelja ( $B=-0,28 ; p<0,01)$ kao najviši završeni stupanj obrazovanja imaju srednju školu rjeđe izražavaju aspiracije za studiranjem u Zagrebu u odnosu na neki drugi grad u Hrvatskoj nego učenici kojima su oba roditelja visokoobrazovana. Nije bilo statistički značajnog učinka za kategoriju učenika čija oba roditelja imaju završenu samo osnovnu školu, vjerojatno zbog relativno malog broja učenika u ovoj kategoriji. Također, nije bilo statistički značajnog učinka za učenike kojima je jedan roditelj visokoobrazovan, a drugi nije. Iz toga proizlazi da učenici imaju više aspiracije za studiranjem u Zagrebu nego u drugim gradovima u Hrvatskoj ako im je barem netko od roditelja fakultetski obrazovan. Nadalje, djeca zaposlenih majki $(B=-0,15 ; p<0,05)$ i očeva $(B=-0,28 ; p<0,05)$ češće odabiru Zagreb kao najpoželjnije mjesto studiranja nego neki drugi grad u Hrvatskoj u usporedbi s djecom nezaposlenih roditelja. Učinak prihoda kućanstva nije bio statistički značajan.

Učenici koji u većoj mjeri smatraju da se obrazovanje u Hrvatskoj cijeni skloniji su aspiraciji za studiranjem u Zagrebu nego u nekom drugom gradu u Hrvatskoj $(B=0,07 ; p<0,05)$. $S$ druge strane, mjere izbjegavanja silazne društvene mobilnosti, samoprocjene vjerojatnosti uspješnog upisa i završetka studija, te procjene nepoštovanja meritokratskih principa u visokom obrazovanju u Hrvatskoj nisu bile u vezi s odabirom Zagreba kao najpoželjnijeg mjesta studiranja u odnosu na neki drugi grad u Hrvatskoj.

Što se tiče kontrolnih regresorskih varijabli, nalazi upućuju na zaključak kako Zagreb kao najpoželjnije mjesto studiranja u odnosu na neki drugi grad u Hrvatskoj češće odabiru učenici gimnazijskih programa $(B=-0,74 ; p<0,01)$, učenici završnih razreda srednje škole u usporedbi s učenicima prvih razreda $(B=-0,31 ; p<0,01)$, učenici višega školskog uspjeha $(B=0,11 ; p<0,01)$ te učenici koji pohađaju školu u Zagrebu ( $B=-2,43 ; p<0,01)$. 
Tablica 2. Rezultati višerazinskoga multinomijalnog regresijskog modela aspiracija prema mjestu studiranja

\begin{tabular}{|c|c|c|c|c|c|c|}
\hline \multirow[t]{2}{*}{ Varijabla } & \multicolumn{3}{|c|}{ Zagreb } & \multicolumn{3}{|c|}{ Inozemstvo } \\
\hline & $\mathrm{B}$ & SE & $\begin{array}{c}\text { Omjer } \\
\text { relativnih } \\
\text { vjerojatnosti }\end{array}$ & $\mathrm{B}$ & SE & $\begin{array}{c}\text { Omjer } \\
\text { relativnih } \\
\text { vjerojatnosti }\end{array}$ \\
\hline \multicolumn{7}{|l|}{ Razina učenika } \\
\hline \multicolumn{7}{|l|}{ Kontrolne varijable } \\
\hline $\begin{array}{l}\text { Vrsta srednjoškolskog } \\
\text { obrazovanja (strukovno) }\end{array}$ & $-0,74^{* *}$ & 0,14 & 0,48 & $-0,60^{* *}$ & 0,14 & 0,55 \\
\hline Rod (ženski) & $-0,02$ & 0,07 & 0,99 & 0,07 & 0,08 & 1,08 \\
\hline \multicolumn{7}{|l|}{ Razred $^{a}$} \\
\hline 1. razred & $-0,31^{* *}$ & 0,09 & 0,73 & $0,43^{* *}$ & 0,11 & 1,54 \\
\hline 3. razred & 0,02 & 0,08 & 1,02 & $0,47^{* *}$ & 0,12 & 1,60 \\
\hline Školski uspjeh & $0,11^{* *}$ & 0,02 & 1,12 & $0,18^{* *}$ & 0,02 & 1,20 \\
\hline \multicolumn{7}{|l|}{ Društveno podrijetlo } \\
\hline \multicolumn{7}{|l|}{ Obrazovanje roditelja ${ }^{\mathrm{b}}$} \\
\hline $\begin{array}{l}\text { Oba roditelja osnovna } \\
\text { škola }\end{array}$ & $-0,25$ & 0,21 & 0,78 & $-1,27^{* *}$ & 0,36 & 0,28 \\
\hline $\begin{array}{l}\text { Jedan roditelj srednja } \\
\text { škola }\end{array}$ & $-0,36^{*}$ & 0,18 & 0,70 & $-0,91^{* *}$ & 0,19 & 0,40 \\
\hline $\begin{array}{l}\text { Oba roditelja srednja } \\
\text { škola }\end{array}$ & $-0,28^{* *}$ & 0,07 & 0,76 & $-0,79^{* *}$ & 0,11 & 0,45 \\
\hline $\begin{array}{l}\text { Jedan roditelj viša } \\
\text { škola ili fakultet }\end{array}$ & $-0,15$ & 0,08 & 0,86 & $-0,41^{* *}$ & 0,10 & 0,66 \\
\hline \multicolumn{7}{|l|}{ Radni status majke ${ }^{c}$} \\
\hline Nezaposlena & $-0,15^{\star}$ & 0,07 & 0,87 & $-0,08$ & 0,10 & 0,92 \\
\hline Umirovljenica & 0,20 & 0,21 & 1,23 & 0,34 & 0,28 & 1,41 \\
\hline $\begin{array}{l}\text { Ne znam / Ne odnosi } \\
\text { se na mene }\end{array}$ & 0,11 & 0,26 & 1,12 & 0,37 & 0,27 & 1,45 \\
\hline \multicolumn{7}{|l|}{ Radni status oca ${ }^{d}$} \\
\hline Nezaposlen & $-0,28^{*}$ & 0,12 & 0,75 & $-0,10$ & 0,13 & 0,91 \\
\hline Umirovljenik & 0,07 & 0,08 & 1,08 & $-0,05$ & 0,12 & 0,95 \\
\hline $\begin{array}{l}\mathrm{Ne} \text { znam / Ne odnosi } \\
\text { se na mene }\end{array}$ & $-0,10$ & 0,18 & 0,91 & 0,13 & 0,22 & 1,14 \\
\hline \multicolumn{7}{|l|}{ Prihodi kućanstva } \\
\hline Do 5000 kn & $-0,17$ & 0,13 & 0,84 & 0,00 & 0,18 & 1,00 \\
\hline $5000-10000 \mathrm{kn}$ & $-0,06$ & 0,11 & 0,94 & $-0,35^{* *}$ & 0,13 & 0,71 \\
\hline $10000-15000 \mathrm{kn}$ & $-0,06$ & 0,09 & 0,94 & $-0,22^{*}$ & 0,11 & 0,80 \\
\hline Ne mogu procijeniti & 0,05 & 0,11 & 1,05 & 0,01 & 0,13 & 1,01 \\
\hline
\end{tabular}




\section{Racionalni izbor}

Izbjegavanje silazne društvene mobilnosti

$0,01 \quad 0,04 \quad 1,01$

Samoprocjena vjerojatnosti uspješnog upisa i završetka studija

Procjena društvene vrijednosti obrazovanja

Procjena nepoštovanja meritokratskih principa u visokom obrazovanju u Hrvatskoj

Razina škole

\section{Kontrolne varijable}

Mjesto školovanja (Neko drugo mjesto u Hrvatskoj)

$-2 \mathrm{LL}$

$-2,43^{* *} \quad 0,18 \quad 0,09$

$-2,62^{* *} \quad 0,23$

0,07

77746,1

AIC

77750,1

BIC

77764,4

$\%$ točnih klasifikacija

$61,5 \%$

Napomena: Kriterijska varijabla je "Koje je za tebe najpoželjnije mjesto za studiranje?" ("Zagreb”, "Neki drugi grad u Hrvatskoj", "Inozemstvo"; referentna kategorija je "Neki drugi grad u Hrvatskoj"). -2LL - -2log vjerojatnost. AIC - Akaikeov informacijski kriterij (engl. Akaike's information criterion). BIC - bayesijanski informacijski kriterij (engl. Bayesian information

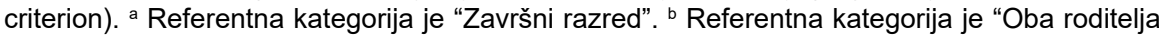
viša škola ili fakultet". " Referentna kategorija je "Zaposlena". ' Referentna kategorija je "Zaposlen". e Referentna kategorija je "Više od 15000 kn". "p $<0,05$. " $p<0,01$.

Vezano za društveno podrijetlo učenika, učenici visokoobrazovanih roditelja češće izražavaju aspiracije za studiranjem u inozemstvu nego u manjem gradu u Hrvatskoj (B Oba roditelja osnovna škola $=-1,27$; $p<0,01$; $B$ Jedan roditelj srednja škola $=-0,91 ; p<0,01 ; B$ Oba roditelja srednja škola $=-0,79 ; p<0,01 ; B$ Jedan roditelj viša škola ili fakultet $=-0,41 ; p<0,01$; referentna skupina: "Oba roditelja viša škola ili fakultet”). Učenici koji žive u kućanstvima s najvišim mjesečnim prihodima (više od 15000 kuna) češće odabiru inozemstvo kao najpoželjnije mjesto studiranja nego neki drugi grad u Hrvatskoj u usporedbi s učenicima iz kućanstava s prihodima od 5000 do 10000 kuna $(B=-0,35 ; p<0,01)$ i od 10000 do 15000 kuna $(B=-0,22 ; p<0,05)$. Pritom nije postojao statistički značajan učinak života u kućanstvima s najmanjim prihodima (do 5000 kuna), kao niti kategorije učenika koji nisu mogli procijeniti prihode svog kućanstva. Također, nije postojao statistički značajan učinak radnog statusa majke i oca. 
Učenici koji daju više procjene izbjegavanja silazne društvene mobilnosti ( $B$ $=0,16 ; p<0,01)$, vjerojatnosti uspješnog upisa i završetka studija $(B=0,12$; $p<0,05)$ te nepoštovanja meritokratskih principa u visokom obrazovanju u Hrvatskoj $(B=0,17, p<0,01)$, u prosjeku češće izražavaju aspiracije za studiranjem $u$ inozemstvu nego u nekom drugom gradu u Hrvatskoj. Jednako vrijedi i za učenike koji smatraju kako se obrazovanje u Hrvatskoj ne cijeni ( $B=-0,19 ; p<0,01)$.

Što se tiče kontrolnih varijabli, inozemstvo kao najpoželjnije mjesto studiranja u odnosu na neki drugi grad u Hrvatskoj češće odabiru učenici gimnazijskih programa $(B=-0,60 ; p<0,01)$, učenici prvih $(B=0,43 ; p<0,01)$ i trećih $(B=0,47 ; p<0,01)$ razreda, učenici višega školskog uspjeha $(B=0,18 ; p<0,01)$ te učenici koji pohađaju škole u Zagrebu ( $B=-2,62 ; p<0,01)$.

Uz ovdje prikazani model, dodatno je provedena i višerazinska multinomijalna regresijska analiza u kojoj su regresorske varijable uvođene u trima sukcesivnim modelima (nije prikazano ovdje zbog nedostatka prostora). U prvom modelu u analizu su uvedene varijable društvenog podrijetla i čimbenika vezanih uz teoriju racionalnog izbora. U drugom su modelu, povrh spomenutih varijabli dodane i kontrolne varijable (vrsta srednjoškolskog obrazovanja, rod, razred, školski uspjeh i mjesto školovanja). Konačno, u trećem modelu u analizu je dodan izbor interakcija regresorskih varijabli (zbog velikog broja varijabli nije bilo moguće testirati sve moguće interakcije). Konkretno, testirane su bivarijatne interakcije roda s obrazovanjem roditelja, prihodima kućanstva i izbjegavanjem silazne društvene mobilnosti te školskog uspjeha s istim tim varijablama. Pokazatelji slaganja modela s podatcima (-2log vjerojatnost, Akaikeov informacijski kriterij i bayesijanski informacijski kriterij) pokazuju kako se treći model (tj. uvođenje interakcija) ne slaže bolje s podatcima od drugog modela. Stoga smo drugi model, koji pridonosi slaganju u odnosu na prvi model, odlučili prikazati u ovom radu (Tablica 2.). ${ }^{4}$

\section{RASPRAVA}

Cilj rada bio je ispitati važnost društvenog podrijetla i različitih čimbenika vezanih uz teoriju racionalnog izbora za aspiracije učenika prema mjestu studiranja. $U$ tu svrhu utvrđuje se moguća povezanost društvenog podrijetla učenika, motiva za izbjegavanjem silazne društvene mobilnosti, samoprocjene vjerojatnosti uspješnog upisa i završetka studija, procjene društvene vrijednosti obrazovanja te procjene nepoštovanja meritokratskih principa (regresorske varijable) s aspiracijama za

4 Pokazatelji slaganja s podatcima za prvi model iznose AIC $=80437,7$ i BIC $=80$ 452,1; za drugi model $\mathrm{AIC}=77$ 750,1 i BIC $=77$ 764,4 te za treći model $\mathrm{AIC}=78$ 053,3 i BIC = 78 067,6. 
studiranjem u Zagrebu i u inozemstvu naspram studiranja u nekom drugom gradu u Hrvatskoj (kriterijska varijabla).

Kako bi se odredili učinci regresorskih varijabli za aspiracije prema mjestu studiranja provedena je višerazinska multinomijalna regresijska analiza. Rezultati te analize pokazali su da je društveno podrijetlo učenika pozitivno povezano $\mathrm{s}$ aspiracijama za studiranjem u inozemstvu, kao i s aspiracijama za studiranjem u Zagrebu, naspram aspiracija za studiranjem u nekom drugom gradu u Hrvatskoj. Točnije, veće aspiracije za studijem u Zagrebu povezane su s visokoškolskim obrazovanjem barem jednog roditelja te s aktivnim radnim statusom majke i oca, dok su veće aspiracije za studijem u inozemstvu povezane s visokim obrazovanjem obaju roditelja i višim mjesečnim obiteljskim prihodima. Moguće objašnjenje te razlike nalazimo u većim roditeljskim očekivanjima vezanim uz studij kad su oba roditelja visokoobrazovana i u činjenici da su troškovi studija u inozemstvu u pravilu viši nego u Zagrebu. Navedeni je nalaz u skladu s istraživanjima koja pokazuju da je udio studenata čiji su roditelji visoko obrazovani veći na Sveučilištu u Zagrebu nego na drugim sveučilištima u Hrvatskoj (Previšić, 1978; Šćukanec i dr., 2015), kao i s nalazima međunarodnih istraživanja koja upućuju na društvenu selektivnost studija u inozemstvu (Di Pietro i Page, 2008; Hauschildt i dr., 2018). Također valja napomenuti da su spomenuti učinci društvenog podrijetla za aspiracije prema mjestu studiranja neovisni o školskom uspjehu ("sekundarni učinci"), što znači da se učenicima deprivilegiranoga društvenog podrijetla, i kad imaju sličan školski uspjeh kao ostali učenici, Zagreb i inozemstvo čine manje poželjnim mjestima studiranja od nekoga drugog grada u Hrvatskoj.

Kao što se očekivalo, veće aspiracije za studiranjem u inozemstvu povezane su i s većom brigom za izbjegavanjem silazne društvene mobilnosti, premda slična veza nije utvrđena kad je riječ o aspiracijama za studijem u Zagrebu. Taj je rezultat na tragu teorijske pozicije prema kojoj inozemni studij, u uvjetima smanjivanja nejednakosti u pristupu visokom obrazovanju, privilegiranim grupama pruža dodatnu mogućnost za osiguranje njihova privilegiranoga obiteljskog statusa. Za razliku od studija u inozemstvu, studij u Zagrebu čini se razmjerno manje poželjnim u kontekstu održanja obiteljskog statusa. Analizom je također utvrđeno da je viša samoprocjena vjerojatnosti uspješnog upisa i završetka studija povezana s većim aspiracijama za studijem u inozemstvu, ali ne i s aspiracijama za studijem u Zagrebu. Ta razlika može sugerirati da studiranje u inozemstvu učenici percipiraju zahtjevnijim i manje izvjesnim od studiranja u Hrvatskoj, pri čemu učenici koji su sigurniji u svoje akademske sposobnosti studiranje u inozemstvu vjerojatno percipiraju manje rizičnim od drugih učenika. Nadalje, dobiveni rezultati pokazuju da učenici koji u većoj mjeri procjenjuju da se u Hrvatskoj obrazovanje cijeni češće izražavaju aspiracije za studijem u Zagrebu, dok, nasuprot tomu, oni učenici koji češće procjenjuju da se 
obrazovanje u Hrvatskoj ne cijeni, češće iskazuju aspiracije za studijem u inozemstvu. Opisani nalaz upućuje na to da učenici aspiracije za mjestom studiranja vežu uz potencijalnu korist od obrazovanja koja ovisi o društvenom kontekstu - primjerice, ako netko smatra da se obrazovanje u Hrvatskoj nedovoljno cijeni, njegove aspiracije za studiranjem u inozemstvu mogu odražavati pretpostavku da inozemni studij povećava šanse za ostankom u inozemstvu kao i za izgradnjom međunarodne karijere. Podatci također pokazuju da učenici koji u većoj mjeri procjenjuju kako se u visokom obrazovanju u Hrvatskoj ne poštuju meritokratski principi češće iskazuju aspiracije za studiranjem u inozemstvu, dok nema povezanosti procjene meritokratskih principa i aspiracija za studiranjem u Zagrebu u odnosu na studiranje u drugim gradovima u Hrvatskoj. Taj bi rezultat mogao značiti da učenici koji su kritični prema visokoškolskom obrazovanju u Hrvatskoj studij u inozemstvu češće percipiraju kao okruženje u kojem se akademska postignuća i sposobnosti vrednuju sukladno meritokratskim principima.

Ukupno uzevši, društveno podrijetlo i različiti čimbenici vezani uz teoriju racionalnog izbora pokazali su se relevantnima za razmatranje učeničkih aspiracija prema mjestu studiranja. Nadalje, provedena analiza upućuje na to da se aspiracije za studiranjem u inozemstvu i u Zagrebu, naspram studiranja u nekom drugom gradu u Hrvatskoj, mogu tumačiti na tragu razvoja horizontalnih nejednakosti u visokom obrazovanju (Netz i Finger, 2016). Taj zaključak podupire nalaz da su, neovisno o školskom uspjehu, aspiracije za studiranjem u Zagrebu povezane s privilegiranim društvenim podrijetlom učenika, dok su aspiracije za studiranjem u inozemstvu, uz privilegirano društveno podrijetlo, povezane i s većim brojem čimbenika koje možemo izravnije dovesti u vezu s mehanizmom izbjegavanja silazne društvene mobilnosti. Ili preciznije, aspiracije za studiranjem u inozemstvu povezane su s većom brigom za održanjem obiteljskog statusa, kao i s čimbenicima koji mogu oblikovati procjenu troškova i dobiti vezanih uz taj motiv (s višom samoprocjenom vjerojatnosti uspješnog upisa i završetka studija, nižom procjenom društvene vrijednosti obrazovanja te višom procjenom nepoštovanja meritokratskih principa u hrvatskom visokom obrazovanju).

Ako se pak naznačeni potencijal za razvoj horizontalnih nejednakosti u visokom obrazovanju promotri u svjetlu recentnih visokoškolskih politika, on može upućivati i na potencijalne prilagodbe našega teorijskog polazišta. Ili preciznije, ako se sve veći broj visokoškolskih programa i karijera bude razvijao na tragu smjernica za stvaranje Europskog prostora visokog obrazovanja (EHEA, 2012), u budućnosti se mogu očekivati pomaci u obrazovnim očekivanjima na tržištima rada, a time i u postignućima potrebnim za međugeneracijsko održanje obiteljskog statusa. U kontekstu teorije racionalnog izbora to bi (sve češće) značilo da za osiguranje privilegiranoga društvenog položaja više nije dovoljno dostići obrazovno postignuće 
roditelja, nego bi ga trebalo nadograditi nekim oblikom međunarodne mobilnosti (primarno unutar Europskog prostora visokog obrazovanja) kao dodatnom kvalifikacijom. Drugim riječima, u novim bi okolnostima izbjegavanje silazne društvene mobilnosti postalo zahtjevnijim za studente privilegiranoga društvenog podrijetla zbog čega bi se taj motiv tendencijski integrirao s aspiracijama za osiguranjem kvalitativnih prednosti u visokom obrazovanju. S druge strane, ako udio studenata koji se odlučuje za studij u inozemstvu ne bude rastao u skladu $s$ očekivanjima obrazovne politike, dio objašnjenja za takav razvoj vjerojatno se može potražiti u mogućnosti da se takav oblik dodatnih kvalifikacija (još) ne prepoznaje u dovoljnoj mjeri kao nužan za međugeneracijsko osiguranje obiteljskog statusa.

Smatramo da navedeni zaključak o povezanosti racionalnosti aspiracija prema mjestu studiranja i međugeneracijskog održanja obiteljskog statusa može poslužiti kao poticaj za daljnja istraživanja horizontalnih nejednakosti u hrvatskom visokom obrazovanju, odnosno za potpunije objašnjavanje tih nejednakosti s aspekta teorije racionalnog izbora - posebno s obzirom na okolnost da je teorija racionalnog izbora u istraživanjima obrazovnih nejednakosti u Hrvatskoj još uvijek podzastupljena. Takvo gledište ne isključuje druge teorijske pristupe koji mogu adresirati obrazovne nejednakosti u hrvatskom kontekstu (Puzić i dr., 2019; Puzić, Gregurović i Košutić, 2018), nego sugerira da kompleksna društvena uvjetovanost tih nejednakosti (Brown i dr., 1997) korespondira s različitim eksplanatornim okvirima.

\section{OGRANIČENJA ISTRAŽIVANJA}

Pri interpretaciji rezultata ovoga rada, treba imati na umu da je kao kriterijska varijabla korištena učenička procjena najpoželjnijeg mjesta za studiranje, a rezultati na ovoj mjeri mogu se bitno razlikovati od učeničkih očekivanja o tome gdje će jednog dana studirati. Razlike mogu biti još veće u odnosu na učeničko stvarno buduće mjesto studiranja. U budućim bi istraživanjima trebalo uzeti u obzir dodatne varijable koje mogu biti važne u kontekstu izbora mjesta studiranja poput procijenjenih troškova života u određenom mjestu, tipa željenog studija (sveučilišnog ili stručnog), poznavanja jezika, procjene vjerojatnosti zapošljavanja nakon završetka studija u određenom mjestu, prosječnog dohotka roditelja na razini škole (s obzirom na to da neke škole okupljaju djecu iz privilegiranijih, a neke iz manje privilegiranih obitelji), veličine mjesta u kojoj se škola nalazi i sl. Procjena društvene vrijednosti obrazovanja i procjena nepoštovanja meritokratskih principa u visokom obrazovanju u Hrvatskoj, koje smo u ovome radu mjerili koristeći se jednočestičnim indikatorima nepoznate valjanosti, složeni su konstrukti koje bi u budućim istraživanjima trebalo odmjeriti većim brojem čestica, odnosno skalama provjerenih metrijskih karakteristika. 


\section{PREPORUKE ZA OBRAZOVNU POLITIKU}

S obzirom na rezultate koji upućuju na vezu društvenog podrijetla i aspiracija za studiranjem u inozemstvu, poželjno je kreirati dodatne mjere podrške međunarodnoj mobilnosti učenika nižega socioekonomskog statusa, primjerice kroz povećanje javnih financijskih potpora i/ili uvođenjem stipendija u tu svrhu. Nadalje, nalaz o povezanosti društvenog podrijetla i aspiracija za studiranjem unutar Hrvatske upućuje na nepovoljan položaj onih učenika kojima socioekonomska situacija ne omogućuje studiranje u Zagrebu. S aspekta proširivanja obrazovnih mogućnosti, taj rezultat upućuje na potrebu za povećanjem ukupno dostupnih financijskih potpora studentima nižega socioekonomskog statusa. S druge strane, činjenica da su učinci društvenog podrijetla za aspiracije prema mjestu studiranja neovisni o uspjehu u srednjoj školi upućuje na važnost sustavnog informiranja učenika srednjih škola o koristi (npr. na tržištu rada) i različitim mogućnostima nastavka obrazovanja na višim razinama.

\section{Financijska potpora}

Rad je nastao u sklopu projekta "Analiza stanja i potreba u srednjoškolskom odgoju i obrazovanju vezanih uz informiranje o visokoškolskim izborima i postupcima upisa na studijske programe preko Nacionalnoga informacijskog sustava prijava na visoka učilišta (NISpVU)" koji je financirala Agencija za znanost i visoko obrazovanje.

\section{LITERATURA}

Arum R, Gamoran A i Shavit Y (2007). More Inclusion Than Diversion: Expansion, Differentiation, and Market Structure in Higher Education. U: Shavit Y, Arum R i Gamoran A (ur.). Stratification in Higher Education: A Comparative Study. Stanford: Stanford University Press, 1-35.

Becker R i Hecken AE (2009). Why are Working-class Children Diverted from Universities? - An Empirical Assessment of the Diversion Thesis, European Sociological Review, 25 (2): 233-250. https://doi.org/10.1093/esr/jcn039

Boudon R (1974). Education, Opportunity, and Social Inequality: Changing Prospects in Western Society. New York: John Wiley and Sons. 
Breen R i Goldthorpe JH (1997). Explaining Educational Differentials: Towards A Formal Rational Action Theory, Rationality and Society, 9 (3): 275-305. https://doi. org/10.1177/104346397009003002

Brown P, Halsey AH, Lauder H i Stuart Wells A (1997). The Transformation of Education and Society: An Introduction. U: Halsey AH, Lauder H, Brown P i Stuart Wells A (ur.). Education: Culture, Economy, Society. Oxford: Oxford University Press, 1-44.

Davies S i Guppy N (1997). Fields of Study, College Selectivity, and Student Inequalities in Higher Education, Social Forces, 75 (4): 1417-1438. https://doi.org/10.2307/2580677

de Wit H i Hunter F (2018). The European Higher Education Area (EHEA): Has It Lost Its Way?. WENR World Education News + Reviews. https://wenr.wes.org/2018/12/theeuropean-higher-education-area-ehea-has-it-lost-its-way (20. veljače 2020.)

Di Pietro G i Page L (2008). Who Studies Abroad? Evidence from France and Italy, European Journal of Education, 43 (3): 389-398. https://doi.org/10.1111/j.1465-3435.2008.00355.x

Dong Y i Peng CJ (2013). Principled Missing Data Methods for Researchers, SpringerPlus, 2, 222. https://doi.org/10.1186/2193-1801-2-222

Državni zavod za statistiku (2018). Studenti upisani na stručni i sveučilišni studij u zimskom semestru ak. g. 2017./2018. Zagreb: Državni zavod za statistiku.

Dwyer MM (2004). More is Better: The Impact of Study Abroad Program Duration, Frontiers: The Interdisciplinary Journal of Study Abroad, 10 (1): 151-164. https://doi.org/10.36366/ frontiers.v10i1.139

EHEA Mobility Strategy (2012). Mobility for Better Learning. Mobility Strategy 2020 for the European Higher Education Area. https://www.cmepius.si/wp-content/ uploads/2014/02/2012-EHEA-Mobility-Strategy.pdf (3. ožujka 2020.)

Gerber TP i Cheung SY (2008). Horizontal Stratification in Postsecondary Education: Forms, Explanations, and Implications, Annual Review of Sociology, 34: 299-318. https://doi. org/10.1146/annurev.soc.34.040507.134604

Goldthorpe JH (1996). Class Analysis and the Reorientation of Class Theory: The Case of Persisting Differentials in Educational Attainment, British Journal of Sociology, 47 (3): 481-505. https://doi.org/10.2307/591365

Hauschildt K, Gwosc C, Netz N i Mishra S (2015). Social and Economic Conditions of Student Life in Europe. Synopsis of Indicators/ EUROSTUDENT V 2012-2015. Bielefeld: W. Bertelsmann Verlag.

Hauschildt K, Vögtle EM i Gwosc C (2018). Social and Economic Conditions of Student Life in Europe. EUROSTUDENT VI 2016-2018/Synopsis of Indicators. Bielefeld: W. Bertelsmann Verlag.

Heck RH, Thomas S i Tabata L (2012). Multilevel Modeling of Categorical Outcomes Using IBM SPSS. New York: Routledge. https://doi.org/10.4324/9780203808986

Hox J, Moerbeek M i van de Schoot R (2018). Multilevel Analysis: Techniques and Applications, Third Edition (Quantitative Methodology Series). New York: Routledge. https://doi.org/10.4324/9781315650982

Jokić B (2019). Obrazovna perspektiva - želje, planovi i stavovi hrvatskih srednjoškolaca o prijelazu iz srednjeg u visoko obrazovanje. U: Ristić Dedić Z i Jokić B (ur.). Što nakon srednje? Želje, planovi i stavovi hrvatskih srednjoškolaca. Zagreb: Agencija za znanost i visoko obrazovanje, 34-63.

Jokić, B i Ristić Dedić, Z (2014). Postati student u Hrvatskoj. Zagreb: Agencija za znanost i visoko obrazovanje. 
Kraaykamp G, Tolsma J i Wolbers MHJ (2013). Educational Expansion and Field of Study: Trends in the Intergenerational Transmission of Educational Inequality in the Netherlands, British Journal of Sociology of Education, 34 (5-6), 888-906. https://doi.org/10.1080/01 425692.2013.816622

Lörtz M, Netz N i Quast H (2016). Why Do Students from Underprivileged Families Less Often Intend to Study Abroad?, Higher Education, 72: 153-174. https://doi.org/10.1007/ s10734-015-9943-1

Lucas SR (2001). Effectively Maintained Inequality: Education Transitions, Track Mobility, and Social Background Effects, The American Journal of Sociology, 106 (6): 1642-1690. https://doi.org/10.1086/321300

Netz N i Finger C (2016). New Horizontal Inequalities in German Higher Education? Social Selectivity of Studying Abroad between 1991 and 2012, Sociology of Education, 89 (2): 79-98. https://doi.org/10.1177/0038040715627196

Powell JJW i Finger C (2013). The Bologna Process' Model of Mobility in Europe: The Relationship of its Spatial and Social Dimensions, European Educational Research Journal, 12 (2): 270-285. https://doi.org/10.2304/eerj.2013.12.2.270

Previšić J (1978). Tko, kako i zašto na fakultet? Socijalno porijeklo i materijalni status redovitih studenata u Hrvatskoj, Pitanja 10 (3): 4-21.

Puzić S, Gregurović M i Košutić I (2018). Kulturni kapital i obrazovne nejednakosti u Hrvatskoj, Njemačkoj i Danskoj: usporedna analiza PISA 2009 podataka, Revija za socijalnu politiku, 25 (2): 133-156. https://doi.org/10.3935/rsp.v25i2.1463

Puzić S, Odak I i Šabić J (2019). Educational Outcomes and Aspirations of Upper Secondary School Students: The Cultural Capital and Relative Risk Aversion Perspectives, Sociologija, 61 (3): 368-388. https://doi.org/10.2298/SOC1903368P

Ristić Dedić Z i Jokić B (2019). Želje, planovi i stavovi hrvatskih srednjoškolaca o prijelazu iz srednjeg u visoko obrazovanje - uvodna razmatranja. U: Ristić Dedić Z i Jokić B (ur.). Što nakon srednje? Želje, planovi i stavovi hrvatskih srednjoškolaca. Zagreb: Agencija za znanost i visoko obrazovanje, 7-12.

Salisbury MH, Umbach PD, Paulsen MB i Pascarella ET (2009). Going Global: Understanding the Choice Process of the Intent to Study Abroad, Research in Higher Education, 50: 119-143. https://doi.org/10.1007/s11162-008-9111-x

Schafer JL (1999). Multiple Imputation: A Primer, Statistical Methods in Medical Research, 8 (1), 3-15. https://doi.org/10.1177/096228029900800102

Sewell WH i Shah VP (1968). Social Class, Parental Encouragement, and Educational Aspirations. American Journal of Sociology, 73 (5): 559-572. https://doi. org/10.1086/224530

Sirin SR (2005). Socioeconomic Status and Academic Achievement: A Meta-Analytic Review of Research, Review of Educational Research, 75 (3): 417-453. https://doi. org/10.3102/00346543075003417

Stocké V, Blossfeld H-P, Hoenig K i Sixt M (2011). Social Inequality and Educational Decisions in the Life Course, Zeitschrift für Erziehungswissenschaft, 14: 103-119. https:// doi.org/10.1007/s11618-011-0193-4

Study.EU (2020). The European Higher Education Area (EHEA). https://www.study.eu/ article/the-european-higher-education-area-ehea (9. ožujka 2020.) 
Šabić J (2019). Populacijska perspektiva - visokoškolski odabiri hrvatskih srednjoškolaca u razdoblju od 2010. do 2017. godine. U: Ristić Dedić Z i Jokić B (ur.). Što nakon srednje? Želje, planovi i stavovi hrvatskih srednjoškolaca. Zagreb: Agencija za znanost i visoko obrazovanje, 136-185.

Šabić J i Jokić B (2019). Elementary School Pupils' Aspirations For Higher Education: The Role Of Status Attainment, Blocked Opportunities And School Context, Educational Studies. https://doi.org/10.1080/03055698.2019.1681941

Šćukanec N, Sinković M, Bilić R, Doolan K i Cvitan M (2015). Socijalni i ekonomski uvjeti studentskog života u Hrvatskoj - Nacionalno izvješće istraživanja Eurostudent $V$ za Hrvatsku za 2014. Zagreb: MZOS.

Van de Werfhorst HG i Hofstede S (2007). Cultural Capital or Relative Risk Aversion? Two Mechanisms for Educational Inequality Compared, The British Journal of Sociology, 58 (3): 391-415. https://doi.org/10.1111/j.1468-4446.2007.00157.x

Van de Werfhorst HG i Luijkx R (2010). Educational Field of Study and Social Mobility: Disaggregating Social Origin and Education, Sociology, 44 (4): 695-715. https://doi. org/10.1177/0038038510369362

Walpole M (2003). Socioeconomic Status and College: How SES Affects College Experiences and Outcomes, The Review of Higher Education, 27 (1): 45-73. https://doi. org/10.1353/rhe.2003.0044 


\title{
To Study Abroad, in Zagreb or in Some Other Croatian City? Social Background, Rationality of Choice and Secondary School Students' Aspirations Towards the Place of Studying
}

\author{
Saša PUZIĆ (iD) orcid.org/0000-0001-7231-7312 \\ Institute for Social Research in Zagreb, Croatia \\ puzic@idi.hr \\ Josip ŠABIĆ (D) orcid.org/0000-0002-8981-2560 \\ Institute for Social Research in Zagreb, Croatia \\ josip@idi.hr \\ Iva ODAK (D) orcid.org/0000-0002-4249-4964 \\ Institute for Social Research in Zagreb, Croatia \\ iva@idi.hr
}

\section{ABSTRACT}

The paper examines the aspirations of Croatian secondary school students towards studying abroad, in Zagreb or in some other city in Croatia. The theoretical background of the paper was based on the rational choice theory, typically used in explaining educational decisions in periods of educational transition. A multi-level multinomial regression analysis was conducted using a nationally representative sample of students attending four-year secondary schools $(\mathrm{N}=10$ 829). The data were collected during the school year 2017/2018. The results indicate that aspirations towards the place of studying are related to the students' social background: stronger aspirations towards studying in Zagreb correlate with having at least one parent with higher education and with the active working status of the mother and father, while stronger aspirations towards studying abroad correlate with the higher education of both parents and a higher monthly household income. Students' aspirations towards studying abroad are also related to the rational choice indicators: greater concern with avoiding downward social mobility, higher estimate of the probability of successful enrolment at and completion of higher education, lower assessment of the value of education in Croatian society and higher assessment of non-compliance with principles of meritocracy in Croatian higher education. On the other hand, aspirations towards studying in Zagreb only correlate with a higher assessment of the social value of education. All effects were independent of the students' school performance. The findings are interpreted in the context of horizontal inequalities in higher education, pointing to possible implications for the educational policy.

Key words: secondary school, aspirations towards the place of studying, rational choice theory, studying abroad, studying in Zagreb, horizontal inequalities 